Case Report

\title{
Exploring the Connections of Education for Sustainable Development and Entrepreneurial Education-A Case Study of Vocational Teacher Education in Finland
}

\author{
Eveliina Asikainen * (D) and Annukka Tapani
}

Citation: Asikainen, E.; Tapani, A. Exploring the Connections of Education for Sustainable Development and Entrepreneurial Education-A Case Study of Vocational Teacher Education in Finland. Sustainability 2021, 13, 11887. https: / / doi.org/10.3390/ su132111887

\section{Academic Editors:}

Jaana Seikkula-Leino,

Mats Westerberg, Priti Verma,

Maria Salomaa and

Adela García-Aracil

Received: 31 August 2021

Accepted: 21 October 2021

Published: 27 October 2021

Publisher's Note: MDPI stays neutral with regard to jurisdictional claims in published maps and institutional affiliations.

Copyright: (c) 2021 by the authors. Licensee MDPI, Basel, Switzerland. This article is an open access article distributed under the terms and conditions of the Creative Commons Attribution (CC BY) license (https:// creativecommons.org/licenses/by/ $4.0 /)$.
Professional Teacher Education, Tampere University of Applied Sciences, Kuntokatu 3, 33520 Tampere, Finland; annukka.tapani@tuni.fi

* Correspondence: eveliina.asikainen@tuni.fi

\begin{abstract}
Education for Sustainable Development (ESD) and Entrepreneurial Education (EE) are quite abstract and demanding concepts for teacher students. Yet, Key Sustainability Competences and Entrepreneurial Competences entail important qualities of future citizens and workers, and teacher students should become prepared to accommodate education for these competencies in their teaching practice. This paper explores teacher students' process of sense-making of sustainable development and how becoming a teacher who practices ESD connects with entrepreneurship. EE serves as a good mirroring surface to ESD as they both have their roots in Transformative Learning (TL) but pursue transformation towards different goals. The case study follows the vocational teacher education (VTE) students' sensemaking of Sustainable Development as a part of teacher's work during one semester which included integrated Thematic Studies of Sustainable Development. The qualitative content analysis of students' texts focused on signs of transformative learning and was guided by the dimensions of sustainable development and learning goals set for teacher's sustainability competences in the VTE curriculum. The results indicate that transformative learning is possible. Furthermore, they address the importance of certain entrepreneurial capabilities in the actualization of change agency.
\end{abstract}

Keywords: education for sustainable development; entrepreneurial education; key sustainability competencies; transformative learning

\section{Introduction}

Education is considered one of the strongest promoters of Sustainable Development (SD), and the need for teacher education to promote teachers' change agency has been identified as one of the critical prerequisites for ecological and societal transition [1,2]. The demand for teachers' capacities to facilitate the development of change making capacities in their students is also clearly stated in the Goal 4.7 of Agenda 2030, saying, "all learners should acquire the knowledge and skills needed to promote sustainable development by 2030." The achievement of this goal should manifest as actions of both teachers and students [3]. Developing educators' capacities and competencies in Education for Sustainable Development (ESD) has been recognized as one of the priority action areas required to address climate change and sustainability challenges in the UNESCO publication Education for Sustainable Development: A Roadmap [4].

Competencies consist of cognitive, affective and motivational elements and a voluntary will and intention of doing things. Each competency is an interplay of knowledge, capacities and skills, motives, and affective dispositions, and their interaction is what matters in the actualization of the competency [5]. Competencies are also situational and context-specific, but transversality can be developed. Key competencies can be understood as multifunctional and context-independent competencies, which are considered to be particularly crucial for implementing societal goals important in a normative framework 
(e.g., sustainability) and which are important for all individuals [5]. In the education profession, competencies of teaching are about promoting learning by combining a teacher's substantial knowledge about an issue, concept, or phenomena with pedagogical knowledge $[5,6]$.

Cebrían and Junyent state ESD competencies focus on the competencies that teachers and educators need to put in place in educational settings to promote sustainability competencies amongst their students [7]. Rieckmann [8] defines teachers' competencies for Education for Sustainable Development as "teacher's capacity to help people develop sustainability competencies through a range of innovative teaching and learning practices" [8] p. 38. The definitions draw attention to the pedagogical competencies and emphasize the competence to transform, which lies in the heart of many other definitions as well (for example, [9] p. 204 and [10]). The transformative dimension of ESD can be stated as follows: "ESD draws on the experience of learners and creates opportunities for participation and for the development of creativity, innovation and the capacity to imagine alternative ways of living. It encourages learners to reflect on the impact of their everyday choices in terms of sustainable development", e.g., [11] p. 17. Thus, the ultimate aim of ESD is to facilitate transformative learning so that people are empowered to take sustainable actions in complex situations [3,12]. To achieve competency to encourage learners to reflect and change their behaviors, teachers should learn about the contents of SD and the concept of ESD, develop in Key Sustainability Competences, and learn how to facilitate all this as educators [13]. Still, a recent review on initial teacher education and ESD discovered a deficit in the development of the professional skills needed to implement ESD, even the students showed positive attitudes towards sustainable development [2]. Often, students do not feel ready or prepared to teach SD topics [14] or have only a partial understanding of $\mathrm{SD}$, often comprising mostly of environmental sustainability [7] or having strong emphasis on social sustainability [15]. Moreover, students' understanding of their possibilities to influence outside school can be weak [15], and they do not consider the competence to teach for a sustainable society as a part of teacher professionalism [14]. One part of the phenomenon seems to be that ESD is often a separate course, and the goal for a teacher to be a promoter of change for a more sustainable world is not made visible in the professional competences or goals of the curriculum $[2,14,16,17]$.

Transformative Learning (TL) theory refers to a qualitative shift in perception and meaning making on the part of the learner, especially when the learner reframes or questions his/her assumptions or habits of thought and becomes critically reflective of those beliefs that become problematic [18]. The broad understanding and general aims of transformative learning are to contribute to a more significant social change (or transformation) through education, which has attracted many ESD scholars to use TL as a theoretical background [19]. For example, Blake et al. [20] p. 5348 describe the need for "that type of learning that is consistent with and helps manifest individual, organizational and social change towards more sustainable practices".

Sterling [21] connects TL with Bateson's [22] models of three orders of learning and change: first-order learning is learning more of the same; second-order learning refers to a significant change in thinking or actions as a result of examining assumptions and values, and it demands the negotiation of meaning; and, finally, third-order learning involves a shift in the operative way of knowing and thinking, in the world view. The levels of learning are connected: second-order or third-order learning also affects our interpretations of our first-order learning, which can show as transformative actions [21].

Even though TL has been used widely as a background theory in ESD [19], the relationship of ESD and TL is not unproblematic [23]. First, the scale of transformation is often blurred in ESD: Any change can be called transformation. Secondly, it is always not at all clear what needs to be sustained and what transformed in transformative ESD [23] p. 306. We apply the strict interpretation of transformative learning, according to which only learning that involves a profound shift in the operative way of knowing and thinking that frames people's perception of, and interaction with, the world—an epistemic change-is 
transformative [21]. It is about being challenged and about becoming conscious of one's worldview. It is not easy or comfortable and demands trusted peers and capable mentors or facilitators [20].

Entrepreneurial education (EE) may seem at first hand a counterpart of ESD, as it is often connected to capitalism and economic growth. On the other hand, there are many ways to define entrepreneurial education [24], and some definitions contain notions of new entrepreneurship that are more connected to ethics, sustainability, sensitivity, and intuitiveness [25]. The connections of EE and Science education are a quite popular research topic [24], but the connections between EE and ESD have not been researched much. For example, the extensive review of Deveci and Seikkula-Leino [24] does not mention any such studies. However, many similarities can be observed easily: making change, the re-examination of assumptions and values, critical thinking, and new creativity can all be found in the learning objectives or competences of ESD and EE [11,26].

Allan Gibb [26] used the term enterprise to mean "a set of behaviors, skills and attributes which may be exhibited by a person". Enterprising behavior has largely been regarded as a vehicle for a change in society with a growing emphasis of managing risks and uncertainty [27]. Gibb's underlying proposition is that there is some enterprise inside every student, and that the inner enterprise can be developed by means of education and training - through EE-which gives freedom, provides ownership, allows control, gives responsibility, allows mistake taking, keeps informal, and provides flexibility in learning situations [26]. Still, clear learning goals are needed, and the teacher's role is essentially to guide, facilitate, and to be a partner in the learning process by focusing on the different ways people learn [19] following the principles of TL. EE also enables students to forecast the future and the changing needs of society and to understand the substance deeply and figure out how it is related to other issues in the society-see "all-overness" [28]. This is clearly key to sustainability competences of systems thinking and anticipatory competency [13] p. 10.

For us, the transformative ambition of ESD and EE provides a lens to examine teachers' competences for ESD. Sustainability and entrepreneurship are both quite abstract ideas as part of vocational teacher's work, even though entrepreneurship has been included in the VTE curricula since the first decade of the 21st century [28] and the ways of proceeding SD in educational institutions has been nationally assessed for 20 years [29,30]. For example, in a recent study on the skills and competencies of Finnish vocational teachers, neither of them was among the 53 identified skills, but the skill of transforming society was a part of Innovator Competency [31].

Vocational teachers are an interesting group of educators for SD. Firstly, they have a professional identity when they start teacher education, and secondly, they will be educating future professionals who should acquire competences mentioned in SDG 4.7, also in relation to their work and professional identity. We find that the vocational teacher students' perceptions of ESD and SD and their perceptions of their professional competencies are particularly important as they affect their future teaching practice and the way they prepare the future professionals who should be able to build a professional identity of being part of the solution in ecological transition.

The concept of sensemaking is useful to describe the process in which the teacher students are trying to grasp concepts which are hard to make concrete: As sensemaking deals, for example, with identity, it is an ongoing and social activity. In addition to that, it offers people extracted cues that provide points of reference for linking ideas for broader networks of meaning [32]. In this paper, we search for answers to the following questions: (1) how students in vocational teacher education make sense of sustainable development as a part of vocational teachers' work and (2) what kinds of connections can be found between education for sustainable development and entrepreneurial education as teachers' competencies. 
We explore these connections via following the development of vocational teacher students' thinking as Thematic Studies in Sustainable Development (TSSD) were integrated to the Vocational Teacher Edcuaction (VTE) programme in Tampere University of Applied Sciences (TampereUAS). The idea of TSSD was not to organize a separate course but to produce materials with pedagogical insights and assessment frames, which the teacher educators could use according to their choice as part of the VTE programme. We take a detailed look at one teacher student groups' learning to understand the students' sense-making of ESD and competencies related to it and make abstract concepts more concrete [32]. To capture the change in the students' perceptions, to identify signs of transformative learning, and to establish how the learning goals connected with transformative learning were achieved, we present the students' thoughts and opinions of teacher's role as a promoter of sustainable development at two points of time. In discussion, we relate the findings to entrepreneurship on conceptual level.

\section{The Case: Introducing ESD Competencies in Vocational Teacher Education Curriculum}

The Finnish VTE programme (60 credits) consists of vocational pedagogical studies, teaching practice, basic studies in education, and elective pedagogical studies. The education is research-based and aims at educating vocational teachers who are able to justify their decisions and actions based on both experience and theory [28]. Most students in vocational teacher education hold a master's degree and at least three years' work experience in the field in which they aim to teach [31]. VTE curriculum in TampereUAS is competency-based [33]. The main pedagogical approach is participatory pedagogy, meaning that the teacher students and their communities are the main actors, and attention is paid to individual learning possibilities and possibilities to demonstrate the skills and competencies the teacher student already has.

The sustainability commitments of TampereUAS have served as drivers for the introduction of ESD competencies in the curriculum. Since 2016, TampereUAS has committed to educating professionals able to further SD in working life and thus stated the will to act out the SDG Goal 4.7. More specifically, the School of Vocational Teacher Education has signed the Climate Challenge of the Teacher Student Union of Finland in 2019 and committed to include education on the competences of promoting climate actions and sustainable practices in vocational colleges in the VTE curriculum [34].

The work for TSSD started by creating a common understanding of sustainable education by a team, which was established in 2020 to promote the integration of sustainability themes in the VTE curriculum and to facilitate their implementation. The common understanding is based on critical thinking and the capability to challenge values and norms as the foundations of sustainable education $[7,35]$. Competences were defined broadly, not only as performance and professional growth but also as human growth, large knowledge foundations, and theoretical thinking: as understandings of principles, moralities, and responsibilities. Acting as a change agent was set in the core of sustainable education and the role of sustainable community culture of an educational institution is addressed; the importance to connect sustainability with the growth of teacher identity and the need to collaborate with working life were emphasised. This served as a basis for describing the core sustainability competences of vocational teachers in relation to the study modules of the present curriculum (Table 1). 
Table 1. Vocational Teachers Sustainability Competencies as defined in Tampere University of Applied Sciences Vocational Teacher Education in 2020 (originally in Finnish, translated by EA).

\section{Vocational Teacher's Sustainability Competences}

Core competence and conceptual base: history and philosophy of sustainable development (SD), ecological, social, cultural, and economic sustainability, Agenda 2030

\begin{tabular}{|c|c|c|c|}
\hline $\begin{array}{cc}\text { Level of } & \begin{array}{c}\text { Competence } \\
\text { competence }\end{array}\end{array}$ & $\begin{array}{l}\text { Teachers in learning } \\
\text { environments and networks }\end{array}$ & $\begin{array}{l}\text { Teachers' professional identity } \\
\text { and pedagogical skills }\end{array}$ & Teachers in society \\
\hline Descriptive & $\begin{array}{l}\text { Student can describe features } \\
\text { of a sustainable educational } \\
\text { institution. } \\
\text { Knows certification systems of } \\
\text { educational institutions. }\end{array}$ & $\begin{array}{l}\text { Recognizes how the teaching } \\
\text { profession connects with SD. } \\
\text { Recognizes the relations of SD } \\
\text { and pedagogical choices. }\end{array}$ & $\begin{array}{l}\text { Knows the agreements and } \\
\text { goals related to SD }\end{array}$ \\
\hline Applying & $\begin{array}{l}\text { Furthers active sustainability } \\
\text { in an educational institution. } \\
\text { Implements the principles of } \\
\text { sustainability at work }\end{array}$ & $\begin{array}{l}\text { Connects professional } \\
\text { knowledge, practices, and } \\
\text { professional identity to form a } \\
\text { sustainable professional identity. } \\
\text { Uses pedagogical solutions } \\
\text { which further SD. }\end{array}$ & $\begin{array}{l}\text { Acts in order to promote SD. } \\
\text { Uses different methods of } \\
\text { influencing and } \\
\text { communication. }\end{array}$ \\
\hline Integrated & $\begin{array}{l}\text { Develops sustainable practices } \\
\text { of an educational institution. } \\
\text { Creates networks. }\end{array}$ & $\begin{array}{l}\text { Acts as a role model for a } \\
\text { sustainability promoting } \\
\text { professional. Develops } \\
\text { pedagogics and contents. }\end{array}$ & $\begin{array}{l}\text { Uses theoretical knowledge } \\
\text { and practical experience to } \\
\text { create a more sustainable } \\
\text { world. }\end{array}$ \\
\hline
\end{tabular}

The ESD competences were described through three competence areas, which matched the study modules of the VTE curriculum: Teachers in learning environments and networks, Teachers' professional identity and pedagogical skills, and Teachers in society. This structure responds to the CSTS model's structuring of competences for ESD [10]. For each competence, the aspects of knowing, doing, and being are described. Mastering the competences was described in three different levels-Descriptive, Applying, and Integrated. The descriptive level goal in each of the three competence areas is based on Knowing about norms and systems. Quite systematically, Doing is emphasized in the descriptions of applied-level mastering and Being in the integrated mastering. Only in the professional development and pedagogical skills is doing already part of the descriptive and being part of the descriptive. This is due to the central role of identity work in this competence area.

The three levels in our learning outcomes resemble the idea behind Stephen Sterling's interpretation of transformative learning [21] based on Bateson's three levels of transformative learning [22]. Students should first learn (more) about SD and its applications in education, then they can change their practices and attitudes. Mastering in the integrated level has elements of epistemic change: "develops sustainable practices", "acts as a role model of a sustainability promoting professional", and "uses theoretical knowledge and practical experience to create a more sustainable world".

We want to emphasise that TSSD was not a separate course. It was designed to be an integrative theme and viewpoint to be discussed in different phases of teacher education and to be independently carried out by the teacher educators of TampereUAS. To ensure the even quality of implementations, learning materials with pedagogical suggestions were produced comprising of an introductory video lecture with slides and linked further readings and suggestions on how to relate the themes into the courses. Materials were made available for all teacher educators through a shared Moodle platform. 


\section{Analysis}

We followed the learning process of one VTE student group $(n=28)$ during their first semester, autumn 2020. Most of the students $(n=25)$ had no prior experience as a teacher in vocational education. Their backgrounds were diverse: from social and health care, culture, engineering, agriculture, and business management to communication. We collected students' thoughts and opinions of teacher's role as a promoter of sustainable development in two occasions.

The first collection of students' ideas of sustainable development and teachers' work took place in September 2020 as the students were introduced to the Thematic Studies in Sustainability. The students had studied the introductory material beforehand and discussed their insights of the phenomenon during the contact day. At the end of the contact day, the students were asked to write a short text (max. one page) with the following instruction: "What does sustainability mean in vocational teacher's work? In what ways it is/it should be visible in vocational teacher's work and in the practices of teaching communities?"

During the semester, the students participated in teaching practice and vocational pedagogical studies. The second collection of students' thoughts on sustainable development and teachers' work took place in November 2020. The students were asked to reflect on their first stories and write shortly about the change. It was expected that seeing the reality of vocational institutes would create a reflective surface for the initial ideas of SD. Ten stories were received (four pages in total). The texts were analysed modifying the grounded theory processes $[11,36]$ : We recognized the role of prior knowledge as mini-frameworks, but analysis involved both theoretical and empirical sensitivity. We attempted to identify specific features of the texts: the context in which the phenomenon was embedded and the conditions that gave rise to it. Although we had prior knowledge of the phenomenon, we tried to be as open as possible to the texts and their voice and reviewed the texts multiple times. The ideas and thoughts presented in the texts were identified to understand the differences and connections between them [12,37].

In our analysis, we combined concept-driven and data-driven qualitative content analysis [38]. Following concept-driven qualitative content analysis [13,38], the expressions were grouped in categories drawn from the theoretical background: the pillars of sustainable development. Table 2 presents the data according to the themes and occasions of data collection. All the teacher students' notions did not, however, fit clearly to the pillars of sustainable development. Some were quite general and focused on the role of education in sustainable development. Here, we applied data-driven analysis [38] and created a category "education for sustainable development", presented in Table 3.

Table 2. The notions of the pillars of sustainable development in students' texts grouped according to the themes and occasions of data collection (1 and 2). Translation by AT.

\section{Ecological 1}

- $\quad$ paying attention to materials used, how to recycle them and save energy

- $\quad$ using more electric tools in teaching, trying to reduce the waste of paper, reusing books

- $\quad$ electric tools are good in teaching but there is still a need for encounterings: students need to be seen and heard, and net-based teaching in not the only good way

- do we need such large spaces in educational institutes

\section{Ecological 2}

- $\quad$ transport: using public transport or bicycling is supported in the institutes

- $\quad$ respecting nature, using nature as a learning possibility; more attention should be paid to aesthetic views of environments

- $\quad$ paying attention to habits in the educational institutes: for example, how the waste food is reduced

- I pay a lot of attention to discussions on the theme 
Table 2. Cont.

\section{Social 1}

- comfortable space is important in feeling welcomed

- $\quad$ supportive working community

- $\quad$ paying attention to special needs students and how to guide them

- $\quad$ supportive culture for learning for all kinds of students

- no bullying

- $\quad$ interaction is important (between teacher and student but also in teacher community)

- $\quad$ justice and equality: for example, trying to help the immigrant students to overcome the language barriers in employment

- $\quad$ open-minded attitudes to different cultures: what we have in common is a good starting point

- there is a need to be unselfish and pay attention to future generations

\section{Social 2}

- I should concentrate on my doings, doing one thing at a time, that would be sustainable

- $\quad$ for me, social and cultural aspects are easier to think about

\section{Cultural 1}

- $\quad$ knowing one's own cultural habits, knowing the cultures nearby and also other cultures

- $\quad$ there is a lot of good things also in the past

- $\quad$ the base elements in life should be arranged before there is a possibility to promote cultural sustainability

\section{Economic 1}

- $\quad$ teachers' work is promoting the economical sustainability while they educate future employees who commit to society and give their work efforts and pay taxes, and so these employees will keep the society going

- $\quad$ all students are not in the same position as far as learning possibilities are concerned-students have different status as financial backgrounds

- durable teaching materials (not only materials that are used once), possibly recycled (has to do with the ecological sustainability, too)

- $\quad$ teacher should stress the proactive way of teaching the skills needed in the future

\section{Economic 2}

- $\quad$ while working in the company, sustainability is one of our business strategies

- $\quad$ some themes that we do in the companies have not landed to educational institutes in a bigger scale yet (such as recycling materials)

Table 3. Notions of education for sustainable development students' texts grouped according to the occasions of data collection (1 and 2).

Education for sustainable development 1

- $\quad$ education plays a big role in supporting sustainability

- $\quad$ sustainability should be a subject in every curriculum

- mutli-professional cooperation, sharing one's expertise

- $\quad$ grouping students and making the environments as collaborative as possible
Education for sustainable development 2

- I have noticed that the phenomena is "all-over"

- $\quad$ should be taken into account everywhere hard to grasp

- what are my real possibilities to promote sustainability as a teacher?

- I would love to work as a teacher and discuss the sustainability questions with my students. Teachers can be a huge value influencer and I would like to be one.

\subsection{Sustainable Development as a Part of Vocational Teachers' Work}

All the pillars of sustainable development were identified in the first texts. More than half of the notions in the first texts were on socially sustainable development: ideas on safety in learning environments, supporting the special needs students, supportive 
teacher communities, sharing the expertise with colleagues, zero tolerance against bullying, notifying meaningful encounterings, and having the future generations in mind. Ecological views concerned the material and recycling issues but also alternative transportation and thoughts on the needs for huge buildings and spaces of educational institutions. The educational profession was seen to be economical when they have a possibility to train future employees and while using sustainable products as teaching materials. Cultural views concerned knowing one's personal life, history, and surroundings. Knowing one's own and local history was regarded as equally important in relation to understanding other cultures. This category was present in the first texts only. In the second texts, the notions were divided more equally between the different pillars of sustainable development and contained thoughts of changing one's own behavior.

The proportion of notions concerning teachers' work was larger in the second collection of data.

In the first texts, students presented the need to include sustainability perspectives in all curricula and identified the importance of education in supporting sustainable development. They also described some pedagogical arrangements which could help in furthering sustainable development such as paying attention to collaboration and multi-professional cooperation in teaching. The second texts tell about beginning to understand the "overallness" of the phenomenon and, at the same time becoming uncertain of teachers' possibilities for promote sustainability. On the other hand, some students express enthusiasm and write about realizing the possibilities a teacher has in influencing future students.

The results of Tables 2 and 3 can be summarized into three main perspectives to make a holistic picture of how the students' understanding of sustainable development as a part of teachers' work develops: the meaningfulness of education, teachers as an example, and understanding the connections.

Concerning the meaningfulness of education, a change in tone can be noticed. The first texts were written more in the style of what ought to be done: There should be sustainability as a core competence for all vocational students and that should be obligatory for all to master in addition to the vocational skills. There was also an understanding that education brings along health and well-being. In the second texts, the students wrote more about the concrete ideas to carry out sustainable things, such as how educational institutions try to support their employees in using public transport or how the waste of food is trying to be avoided. There was also an example of how to bring some nature elements into the classrooms and referring to that it is said to increase the ecological thinking in addition to that it could be used as a teaching tool. At the same time, students presented their individual feelings towards teachers' possibilities: both hesitation and enthusiasm.

In the first texts, teachers as an example was more about knowing how, organizing the learning environments to act, and knowing about the facts, for example, sharing expertise and making environments as collaborative as possible. In the second texts, understanding was more on affecting the students: willingness to discuss the themes with students and to be more coherent of one's own doings, such as trying not to concentrate on multiple things at the same time.

Understanding the connections was described in the first texts more in terms of "hope to do these things". The students described understanding of different cultures and beautiful learning environments. They wanted to encourage students to think on their own behavior and its effects. In the second stories, there was more understanding of sustainability as a phenomenon everywhere. Their eyes were opened to it as being "all over the world". They were a little concerned about how it is everywhere, but it is difficult to grasp and make concrete.

The results indicate that students' first texts were written usually from a viewpoint of an observer and the second texts more from a viewpoint of a member of the teacher community. This we consider as the beginning of sensemaking, remarkable transformative learning in three months, and as an initiation of the development of teacher identity. 


\subsection{Meeting the Learning Objectives of the Course}

To reflect on how the goals set when planning the TSSD were achieved, we connected the teacher students' thoughts and observations with the expected learning outcomes (Table 4). This analysis was carried out as a concept-driven analysis using the descriptions of learning outcomes as the basis of the categories. This analysis shows that teacher students' thoughts and reflections meet the applying and even the integrated level of mastering in the latter texts. The students seemed to have encountered new thoughts which have changed their way of looking at teachers' work and their understanding of the power and potential to make change through teachers' work. Even though the students were not working as teachers, some of them have reached the integrated level in their writings on how teachers can act as examples of sustainably acting and responsible professionals. Altogether, students were able to recognize practical examples of actions for sustainable development in educational institutions. However, they did not produce notions of the certification systems or descriptions of the agreements in the background of sustainable development.

Table 4. Learning on sustainability competences shown in the students' texts (in italics) and Vocational Teacher's Sustainability Competences as defined in Tampere University of Applied Sciences Vocational Teacher Education in 2020.

\section{Vocational Teacher's Sustainability Competences}

Core competence and conceptual base: history and philosophy of sustainable development (SD), ecological, social, cultural, and economical sustainability, Agenda 2030

\begin{tabular}{|c|c|c|c|c|}
\hline $\begin{array}{l}\text { Level of } \\
\text { compe- } \\
\text { tence }\end{array}$ & $\begin{array}{l}\text { Frame of } \\
\text { Competence } \\
\text { according to } \\
\text { the study } \\
\text { modules }\end{array}$ & $\begin{array}{l}\text { Teachers in learning } \\
\text { environments and networks }\end{array}$ & $\begin{array}{l}\text { Teachers' professional identity } \\
\text { and pedagogical skills }\end{array}$ & Teachers in society \\
\hline De & iptive & $\begin{array}{l}\text { Students can describe features } \\
\text { of a sustainable educational } \\
\text { institution. } \\
\text { Students could recognize practical } \\
\text { examples in educational } \\
\text { institutions. } \\
\text { Knows certification systems of } \\
\text { educational institutions. (not } \\
\text { visible in the data) }\end{array}$ & $\begin{array}{l}\text { Recognizes how the teaching } \\
\text { profession connects with SD. } \\
\text { Recognizes the relations of SD } \\
\text { and pedagogical choices. } \\
\text { Reflections on the impact of } \\
\text { education. }\end{array}$ & $\begin{array}{c}\text { Knows the agreements and } \\
\text { goals related to SD (not } \\
\text { visible in the data) }\end{array}$ \\
\hline & lying & $\begin{array}{c}\text { Furthers active sustainability } \\
\text { in an educational } \\
\text { institution.Implements the } \\
\text { principles of sustainability at } \\
\text { work } \\
\text { Students seem to pay more } \\
\text { attention to sustainability in } \\
\text { vocational teacher's work. }\end{array}$ & $\begin{array}{l}\text { Connects professional } \\
\text { knowledge, practices, and } \\
\text { professional identity to form a } \\
\text { sustainable professional identity. } \\
\text { Uses pedagogical solutions } \\
\text { which further SD. } \\
\text { Especially the social points are } \\
\text { recognized-the core of being a } \\
\text { vocational teacher. }\end{array}$ & $\begin{array}{l}\text { Acts in order to promote SD. } \\
\text { Uses different methods of } \\
\text { influencing and } \\
\text { communication. } \\
\text { The power of teacher being an } \\
\text { example is recognized. }\end{array}$ \\
\hline \multicolumn{2}{|c|}{ Integrated } & $\begin{array}{l}\text { Develops sustainable practices } \\
\text { of an educational institution. } \\
\text { Creates networks. } \\
\text { Most of the teacher students are } \\
\text { not working as teachers yet. Clear } \\
\text { reflections outside the teacher } \\
\text { communities. }\end{array}$ & $\begin{array}{l}\text { Acts as a role model for a } \\
\text { sustainability promoting } \\
\text { professional. Develops } \\
\text { pedagogies and contents. } \\
\text { Well-defined the idea of the teacher } \\
\text { being an example. During studies, } \\
\text { broadened views to the phenomenon. }\end{array}$ & $\begin{array}{l}\text { Uses theoretical knowledge } \\
\text { and practical experience to } \\
\text { create a more sustainable } \\
\text { world. } \\
\text { The journey has started by } \\
\text { thematic studies. It is the } \\
\text { responsibility of teacher } \\
\text { educator to keep discussions } \\
\text { alive during the study process. }\end{array}$ \\
\hline
\end{tabular}


As we took a critical view on the course implementation, we realized that it was no surprise that students did not take the documents of sustainability into account: There were no lectures or documents available for that. Some teacher students were aware of the documents in their previous working places but have not seen any documents when visiting the educational institutes. Furthermore, the students who had no prior experience in teaching were quite keen on becoming acquainted with the teaching and learning environments. Encounterings - that is, many kinds of situations of close and authentic interaction-have played a big role during the studies and discussions on how to keep every student along, so it was no wonder that they commented most on the social dimensions of sustainability.

\section{Discussion}

Separate courses on ESD have been reported to be somewhat inefficient in creating change agency in teachers $[2,7,14,15]$. For example, [14-17] call for a more holistic inclusion of sustainability in strategies and curricula of teacher education. Especially [14] addresses the power of making sustainability competency a visible professional goal in the curriculum. Thematic studies were an attempt to answer these calls by providing a sustainability lens to the teaching profession instead of a separate course. The reflections of the students point to the direction that strong integration with the identity process provides an important ingredient for enabling transformative learning towards ESD.

As promotion of SD is not commonly identified as a part of vocational teachers' work [31], it is not surprising that the students' first texts were generally quite descriptive and resembled answers to a test or described their expectations. The second ones were written with more subjective tones, presenting observations of how sustainability relates with education and describing teachers' roles in promoting sustainability. All this speaks about ongoing sensemaking [32].

The sensemaking process started with grasping what SD is and, at the same time, trying to understand what is a teacher's role in this. The latter texts contain thoughts, both inspired and hesitant, about teachers' possibilities. We interpret the inspired thoughts as becoming aware of the transformative power of a teacher in the context of SD, which is a step towards acting for such transformation as a teacher. Beyond the possibilities of an individual teacher, students also described the practicalities of educational institutions and possibilities to make change in them. Students have become aware of sustainability and its "all-overness" and can identify teachers' transformative role in the educational institution [39].

The hesitant notions are reflections of teacher students becoming more aware of the "doing and being" potentials of teachers. This is related to becoming aware of how huge and difficult a phenomenon sustainability is [15]. The next step would be to start thinking about how to realize sustainability in their teaching practice. Whether subjective observations on practices, teachers' potentials and possibilities to promote SD on the level of educational institutions are actualized as change agency and depend greatly on the interplay of all aspects of the ESD competency but especially of motives and affective dispositions [5] during teaching practice or in the school community. This is the phase where students' courage for transformative learning can fail if they are not around trusted peers and a teacher educator who is a capable mentor or facilitator [20] who guides, facilitates, and partners $[2,26]$ with them in the learning process. Starting to practice ESD demands competencies of risk taking and withstanding uncertainty and ambiguity, which can be described as entrepreneurial [40]. Here, entrepreneurial education seems to have something to offer for ESD as the pedagogies for ESD address poor tolerances for ambiguity and uncertainty [41], and do not even recognize risk taking as it is not considered a Key Sustainability Competence, while these competences are in the heart of entrepreneurial education [27].

Finally, some students wrote about changes in their world view. The introductory materials on sustainability, instructed ponderations, and other studies steered the students 
to observe ecological and social sustainability in educational institutions and curricula. This directed some students to choose sustainability-inclined topics for Development Works (5 ect), such as "how to teach regenerative farming" or "trying to figure out eco-sociological social work or studying how garden work could be implemented as many possible studies". In these students, the studies have ignited the will to act as change agents in educational institutions, and they show the actualization of change, which is coming close to third-order learning [22].

As some of the students have actually made choices which alter their professional development towards a change agent, we find that we have been able to create studies which can open students' eyes to the meaning of their choices concerning the sustainable future and sustainable life, thus providing some evidence of third-order transformative learning [21]. Some of this is undoubtedly due to the teacher education process being an identity-building process with strong group dynamics. It seems that introducing the theme of ESD in the beginning of studies directed the students' attention to the sustainability themes in an early phase of making sense of the whole profession and facilitated integrating the mission of sustainability as part of the professional growth [17]. In our opinion we have developed one way to incorporate ESD in teacher education in a way that meets the challenge of establishing "professional development approaches and opportunities that would enable teaching colleagues to prepare students ... to understand and apply their professional and global responsibilities in sustainability [2]."

We have followed only one student groups' learning and only for a short time. Thus, we cannot generalize our results. Still, we find this case and its results quite promising. Transformative learning processes can take a long time, and the seeds sown in teacher education may manifest later in during the teaching career. More initiatives and more research on the connections of ESD and EE would be needed to better understand how their transformative capacities can best be combined for a more sustainable future through teacher education.

\section{Conclusions}

In the beginning of the paper, we stated that transformative learning connects ESD and EE and noted that many of the competences are related. On the other hand, some contents and commitments are contradictory, most visibly the commitment to economic growth in mainstream definitions of EE [24]. Through our case study, and especially through students' learning outcomes, we propose that it would be important to the recognize Gibb's [26] inner enterprise as a crucial component of an active educator striving to transform educational practices and institutions. Especially the entrepreneurial competencies of risk-taking and standing uncertainty and ambiguity could add to the agency of student when connected with the often-emphasized intra-personal competencies such as collaboration and empathy [3]. Addressing these competencies demands the same capacities also from the teacher educators, which addresses how demanding it is to design transformative learning processes.

We find that the developed model for integrating the sustainability theme into VTE offers teacher students a trigger to start making sense of the teacher profession and educational institutions through the sustainability lenses, to develop their sustainability competences. It is important to note that the students' transformative learning process does induce ambiguity and doubts. Here, some perspectives of entrepreneurial education can be useful: especially paying attention to the encouragement, risk-taking, and withstanding the uncertainty of change making.

It is also important to understand that the integrated mastering of transformative sustainability competences can develop only in encounters with authentic teaching and learning situations and with working life. For this to take place, the sustainability theme has to live all through the curriculum, and the inner enterprise of students has to be strengthened through the pedagogical choices of guiding, facilitation, encouraging to take risks and to try new teaching methods, and by partnering in the learning process by focusing 
on the different ways people learn. These solutions would allow for the transformative learning and growth of vocational teachers who strive for educating professionals who are willing and capable to take action to carry out sustainable transitions.

As a more general conclusion, we highlight the importance of making the sustainability competencies visible as part of the education profession in teacher education curricula and providing teacher educators with the capacities which facilitate transformative learning.

Author Contributions: Concepts and background, E.A. and A.T.; curriculum development, E.A.; case study with students, A.T.; writing, E.A. and A.T. All authors have read and agreed to the published version of the manuscript.

Funding: This research received no external funding.

Institutional Review Board Statement: Ethical review and approval were waived for this study, due to that the research does not deal with vulnerable groups or sensitive issues.

Informed Consent Statement: Informed consent was obtained from all subjects involved in the study. Preliminary results of the study were presented to the students. Individual students cannot be identified from the study.

Data Availability Statement: Data available on request due to restrictions of privacy.

Acknowledgments: We want to thank the teacher students for versatile, honest and inspiring answers.

Conflicts of Interest: The authors declare no conflict of interest.

\section{References}

1. UNESCO. Progress on Education for Sustainable Development and Global; UNESCO: Paris, France, 2018.

2. Pegalajar-Palomino, M.D.C.; Burgos-García, A.; Martinez-Valdivia, E. What does education for sustainable development offer in initial teacher training? A systematic review. J. Teach. Educ. Sustain. 2021, 23, 99-114. [CrossRef]

3. Giangrande, N.; White, R.M.; East, M.; Jackson, R.; Clarke, T.; Coste, M.S.; Penha-Lopes, G. A competency framework to assess and activate education for sustainable development: Addressing the UN sustainable development goals 4.7 challenge. Sustainability 2019, 11, 2832. [CrossRef]

4. UNESCO. Education for Sustainable Development: A Roadmap; UNESCO: Paris, France, 2021.

5. Rieckmann, M. Future-oriented higher education: Which key competencies should be fostered through university teaching and learning? Futures 2012, 44, 127-135. [CrossRef]

6. Shulman, L.S. Those who understand: Knowledge growth in teaching. Educ. Res. 1986, 15, 4. [CrossRef]

7. Cebrián, G.; Junyent, M. Competencies in education for sustainable development: Exploring the student teachers' views. Sustainability 2015, 7, 2768-2786. [CrossRef]

8. Rieckmann, M. Education for sustainable development in teacher education. An international perspective. In Environmental Education; Lahiri, S., Ed.; Studera Press: Delhi, India, 2019; pp. 33-48.

9. Wiek, A.; Withycombe, L.; Redman, C.L. Key competencies in sustainability: A reference framework for academic program development. Sustain. Sci. 2011, 6, 203-218. [CrossRef]

10. Sleurs, W. Competencies for ESD (Education for Sustainable Development) Teachers: A Framework to Inte-Grate ESD in the Curriculum of Teacher Training Institutes. Available online: https://unece.org/fileadmin/DAM/env/esd/inf.meeting.docs/ EGonInd/8mtg/CSCT\%20Handbook_Extract.pdf (accessed on 31 January 2008).

11. UNECE. Learning for the Future: Competences in Education for Sustainable Development; United Nations Economic Commission for Europe: Geneva, Switzerland, 2012.

12. Sterling, S.; Glasser, H.; Rieckmann, M.; Warwick, P. competencies. In Envisioning Futures for Environmental and Sustainability Education; Wageningen Academic Publishers: Wageningen, The Netherlands, 2017; pp. 153-168.

13. UNESCO. Education for Sustainable Development Goals: Learning Objectives; UNESCO: Paris, France, 2017.

14. Dahl, T. Prepared to teach for sustainable development? Student teachers' beliefs in their ability to teach for sustainable development. Sustainability 2019, 11, 1993. [CrossRef]

15. Koskela, T.; Kärkkäinen, S. Student teachers' change agency in education for sustainable development. J. Teach. Educ. Sustain. 2021, 23, 84-98. [CrossRef]

16. Wolff, L.-A.; Sjöblom, P.; Hofman-Bergholm, M.; Palmberg, I. High performance education fails in sustainability?-A reflection on Finnish primary teacher education. Educ. Sci. 2017, 7, 32. [CrossRef]

17. Raus, R. Student teacher ecological self in the context of education for sustainable development: A longitudinal case study. J. Educ. Sustain. Dev. 2017, 11, 123-140. [CrossRef] 
18. Mezirow, J. Learning as Transformation: Critical Perspectives on a Theory in Progress; Jossey-Bass Publishers: San Fransisco, CA, USA, 2000

19. Aboytes, J.G.R.; Barth, M. Transformative learning in the field of sustainability: A systematic literature review (1999-2019). Int. J. Sustain. High. Educ. 2020, 21, 993-1013. [CrossRef]

20. Blake, J.; Sterling, S.; Goodson, I. Transformative learning for a sustainable future: An exploration of pedagogies for change at an alternative college. Sustainability 2013, 5, 5347-5372. [CrossRef]

21. Sterling, S. Transformative learning and sustainabiity: Sketching the concpetual ground. Learn. Teach. High. Educ. 2011, 5, 17-33.

22. Bateson, G. Steps to an Ecology of Mind; Chandler: San Fransisco, CA, USA, 1972.

23. Selby, D.; Kagawa, F. Teetering on the brink: Subversive and restorative learning in the times of climate turmoil and disaster. J. Transform. Educ. 2018, 16, 302-322. [CrossRef]

24. Deveci, I.; Seikkula-Leino, J. A review of entrepreneurship education in teacher education. Malays. J. Learn. Instr. 2018, 15, 105-148. [CrossRef]

25. Rae, D. Universites and enterprise-education: Responding to the challenges of the new era. J. Small Bus. Enterp. Dev. 2010, 17, 591-606. [CrossRef]

26. Gibb, A.A. Enterprise culture and education: Understanding enterprise education and its links with small business, entrepreneurship and wider educational goals. Int. Small Bus. J. 1993, 11, 11-34. [CrossRef]

27. Gabrielsson, J.; Hägg, G.; Landström, H.; Politis, D. Connecting the past with the present: The development of research on pedagogy in entrepreneurial education. Educ. Train. 2020, 62, 1061-1086. [CrossRef]

28. Seikkula-Leino, J.; Ruskovaara, E.; Hannula, H.; Saarivirta, T. Facing the changing demands of Europe: Integrating entrepreneurship education in Finnish teacher training curricula. Eur. Educ. Res. J. 2012, 11, 382-399. [CrossRef]

29. Rajakorpi, A.; Salmio, K. Toteutuuko Kestävä Kehitys Kouluissa Ja Oppilaitoksissa; National Board for Education: Helsinki, Finland, 2001.

30. Räkköläinen, M. Kestävän Kehityksen Osaaminen, Opetus Ja Koulutuksen Järjestäminen Ammatillisissa Perustutkinnoissa; Kansallinen koulutuksen arviointikeskus: Helsinki, Finland, 2017.

31. Tapani, A.; Salonen, O.A. Identifying teachers' competencies in Finnish vocational education. Int. J. Res. Vocat. Educ. Train. 2019, 6, 243-260. [CrossRef]

32. Weick, K.E. Sensemaking in Organisations; Sage: London, UK, 1995.

33. TAMK. Vocational Teacher Education-Curriculum; TAMK: Tampere, Finland, 2020.

34. SOOL-Teacher Students Union in Finland. Nämä Opettajankoulutusyksiköt Osallistuivat Soolin Ilmastohaasteeseen. Available online: https:/ / www.sool.fi/uutiset/nama-opettajankoulutusyksikot-osallistuivat-soolin-ilmastohaasteeseen/ (accessed on 14 May 2021).

35. Asikainen, E.; Kukkonen, H.; Hakala, K.; Harju, E.; Kyhä, H.; Lahtinen, J.; Nevalainen, V.; Ranne, P.; Tapani, A. Kohti Kestävää Koulutusta ja Opettajuutta. TAMKJournal 2020. Available online: https:/ / sites.tuni.fi/tamk-julkaisut/pedagogiset-ratkaisut/ kohti-kestavaa-koulutusta-ja-opettajuutta/ (accessed on 3 September 2020).

36. Corbin, J.; Strauss, A. Basics of Qualitative Research: Grounded Theory Procedures and Techniques; Sage Publications: London, UK, 1990.

37. Kleinsasser, R.C.; Silverman, D. Interpreting qualitative data methods for analysing talk, text and interaction. Mod. Lang. J. 1997, 81, 136. [CrossRef]

38. Schreirer, M. Qualitative Content Analysis in Practice; Sage: London, UK, 2012.

39. Rauch, F.; Steiner, R. Competences for education for sustainable development in teacher education. CEPS J. 2013, 3, 9-24.

40. EntreComp. The European Entrepreneurship Competence Framework. Available online: https://ec.europa.eu/social/main.jsp? catId $=1317 \&$ langId=en (accessed on 18 August 2021).

41. Lozano, R.; Merrill, M.Y.; Sammalisto, K.; Ceulemans, K.; Lozano, F.J. Connecting Competences and Pedagogical Approaches for Sustainable Development in Higher Education: A Literature Review and Framework Proposal. Sustainability 2017, 9, 1889. [CrossRef] 